\title{
Influence of the Simultaneous Addition of the Protease Flavourzyme and the Lipase Novozym 677BG on Dry Fermented Sausage Compounds Extracted by SDE and Analyzed by GC-MS
}

\author{
Diana Ansorena, I ciar Astiasarán,* and J osé Bello \\ Departamento de Bromatología, Toxicología y Tecnología de Alimentos, Facultad de Farmacia, \\ Universidad de Navarra, 31080 Pamplona, Spain
}

\begin{abstract}
A dry fermented sausage (chorizo de Pamplona) was elaborated with the simultaneous addition of a lipase (Novozym 677BG) and a protease (Flavourzyme) and ripened during 21 days, in contrast to the control without enzymes and ripened during 35 days. Faster and more intense lipolytic and proteolytic activities were observed in the modified sausage, despite its shorter maturation time. At the end of the ripening, a determination of the profile of compounds extracted by simultaneous distillation-extraction with dichloromethane was carried out. The total amounts of extracted compounds (expressed in milligrams of dodecane per gram of dry matter) were 2.5 in the sausage with enzymes and 1.9 in the control. The chemical groups showing increments due to the use of enzymes were esters (103.5\% increment) and acids ( $87 \%$ increment) in both cases due to the greater presence of long-chain fatty acid products. However, development of substances originated from further degradation process of amino acids and free fatty acids did not seem to have taken place.
\end{abstract}

Keywords: Dry fermented sausages; enzymes; SDE profile

\section{INTRODUCTION}

The use of lipolytic and proteolytic enzymes in dry fermented sausage could increase the development of volatile compounds through a greater synthesis of their precursors. The improvement of sensorial quality of these products using enzymes requires the determination of volatile compounds so that it could be possible to evaluate their role in the development of higher quality and better acceptability of products (García Regueiro and Díaz, 1995).

Addition of proteases and lipases to dry fermented sausages to shorten the ripening time has been used since the early 1990s (Ordoñez et al., 1998). It has been well stablished that this strategy leads to many changes in the lipidic and nitrogen fractions, depending on the kind of enzyme and the dose employed, with certain repercussions in the sensorial properties of the products (Díaz et al., 1996, 1997; Fernández et al., 1995; Zalacain et al., 1997a-c; Zapelena et al., 1998, 1999). Furthermore, when a lipase and a protease were added simultaneously to the manufacture of chorizo de Pamplona, a typical Spanish sausage, significant increases in some amino acids and some free fatty acids were found, but no differences were detected in the sensory quality, compared with the control, except for a slight softening (Ansorena et al., 1998).

Compounds resulting from protein breakdown and lipolysis and those originated by their transformation into volatile and sapid substances play an important role in the flavor of dry fermented sausages. However, not many papers focus attention on the determination of the influence of the use of enzymes on the volatile profile of the sausages. Hagen et al. (1996) identified

* To whom correspondence should be addressed (phone 948425600; fax 948-425649; e-mail iastiasa@unav.es).
45 different compounds in a model salami (without spices and without smoking) and detected a significant effect on 9 of them in those treated with a protease from Lactobacillus paracasei subsp. paracase (NCDO 151 proteinase). Maturity flavor was more pronounced in sausages with NCDO 151 proteinase added, even if the ripening time was shorter.

Bruna et al. (1998) tested the simultaneous use of a protease (Pronase E) and a mold extract (from Penicillium ol sonii) to potentiate the dry fermented sausage flavor. They found similar volatile compound patterns for all elaborated batches, although those with the protease and the mold extract showed the highest concentration, followed by those with only the protease. No effects were found on odor, rancid flavor, and flavor intensity.

The objective of this work was to evaluate the modification on the development of the compounds extracted by simultaneous distillation-extraction (SDE) in a dry fermented sausage, as a consequence of the proteolytic and lipolytic activity caused by the simultaneous addition of a lipase from Thermomyces lanuginosus (Novozym 677BG) and a commercial mixture of exo- and endoproteases from Aspergillus oryzae (Flavourzyme).

\section{MATERIAL AND METHODS}

Sausage Elaboration. Sausages containing lipase and protease and a control sausage (without enzymes) were made in a pilot plant. The lipase was Novozym 677BG, a microbial enzyme from $T$. Ianuginosus (Novo Nordisk $A / S$ ), and the protease was Flavorzyme (Novo Nordisk A/S), a mixture of proteases with both exo- and endopeptidase activities, obtained by the controlled fermentation of $A$. oryzae A mixture of Lactobacillus plantarum L 115 (10\%) and Staphyl ococcus carnosus M72 (90\%) from Lacto-Labo (TEXEL) was used as starter culture at $10^{6}-10^{7}$ col ony-forming units (cfu)/g. 
Table 1. Evolution of Content (Milligrams of Tyr per Gram of Dry Matter) in Total $\alpha-\mathrm{NH}_{2}$ Groups during the Ripening Time $^{a}$

\begin{tabular}{lllllll}
\hline & \multicolumn{1}{c}{ mixing } & \multicolumn{1}{c}{3 days } & \multicolumn{1}{c}{9 days } & \multicolumn{1}{c}{15 days } & 21 days & 35 days \\
\hline control & $25.51 \pm 0.43 a$ & $33.15 \pm 1.10 \mathrm{~b}$ & $38.66 \pm 2.97 \mathrm{c}$ & $40.57 \pm 2.19 \mathrm{~d}$ & $43.57 \pm 1.74 \mathrm{e}$ & $46.63 \pm 1.50 \mathrm{e}$ \\
enzymes & $25.51 \pm 0.43 \mathrm{a}$ & $44.33 \pm 3.71 \mathrm{~b}$ & $49.77 \pm 1.12 \mathrm{c}$ & $54.56 \pm 2.73 \mathrm{~d}$ & $58.02 \pm 3.73 \mathrm{e}$ & \\
SL & ns & $* *$ & $* * *$ & $* * *$ & $* *)$
\end{tabular}

a Student t test: SL (significance level); ns, not significant, $\mathrm{p}>0.05 ; * *, \mathrm{p}<0.01 ; * * *, \mathrm{p}<0.001 ;(* *)$ between control sausage with 35 days and sausages with enzymes with 21 days. ANOVA: within the same row different letters denote significant differences among phases of analysis $(p<0.05)$

Table 2. Evolution of Acidity Value (Grams of Oleic Acid per $100 \mathrm{~g}$ of Fat) during Ripening Timea

\begin{tabular}{lllllll}
\hline & \multicolumn{1}{c}{ mixing } & \multicolumn{1}{c}{3 days } & \multicolumn{1}{c}{9 days } & 15 days & 21 days & 35 days \\
\hline control & $2.10 \pm 0.10 \mathrm{a}$ & $3.19 \pm 0.07 \mathrm{~b}$ & $3.93 \pm 0.14 \mathrm{c}$ & $4.75 \pm 0.10 \mathrm{~d}$ & $5.50 \pm 0.13 \mathrm{e}$ & $5.67 \pm 0.05 \mathrm{e}$ \\
enzymes & $2.10 \pm 0.10 \mathrm{a}$ & $3.95 \pm 0.09 \mathrm{~b}$ & $5.95 \pm 0.19 \mathrm{c}$ & $7.44 \pm 0.09 \mathrm{~d}$ & $9.61 \pm 0.20 \mathrm{e}$ & \\
SL & $\mathrm{ns}$ & $* * *$ & $* * *$ & $* * *$ & $* * *(* *)$
\end{tabular}

a Student t test: SL (significance level); ns, not significant, $\mathrm{p}>0.05$; ***, $\mathrm{p}<0.001$; (***) between control sausage with 35 days and sausages with enzymes with 21 days. ANOVA: within the same row different letters denote significant differences among phases of analysis $(p<0.05)$

The two types of sausages were made with a standard formulation comprising lean pork meat $(70 \%)$, pork back fat (30\%), red pepper (30 g/kg), NaCl ( $28 \mathrm{~g} / \mathrm{kg})$, dextrin (15 g/ $/ \mathrm{kg})$, powdered milk (12 g/kg), lactose (10 g/kg), sodium caseinate $(10 \mathrm{~g} / \mathrm{kg})$, dextrose $(5 \mathrm{~g} / \mathrm{kg})$, garlic $(3 \mathrm{~g} / \mathrm{kg})$, polyphosphates (2 $\mathrm{g} / \mathrm{kg}$ ), Curavi (a mixture of nitrate and nitrite; $0.3 \mathrm{~g} / \mathrm{kg}$ ), and Ponceau 4R (E-124; $0.3 \mathrm{~g} / \mathrm{kg})$.

Lean pork meat and fat back pork were minced in a cutter to a particle size of $\sim 3 \mathrm{~mm}$ (this small particle size is a characteristic of chorizo de Pamplona, a Spanish type of dry fermented sausage). Subsequently, all ingredients and the starter culture were added and mixed in a vacuum kneading machine. The mixture was divided into two batches of $7 \mathrm{~kg}$ each. Lipase $(0.500 \mathrm{LU} / \mathrm{g}$ of mixture) and protease $(0.02$ $\mathrm{LAPU} / \mathrm{g}$ of mixture) were added to batch 1 , and no enzymes were added to batch 2 (control). After the initial fermentation in a ripening cabinet [ $24 \mathrm{~h}$ at $24{ }^{\circ} \mathrm{C}$ and $100 \%$ relative humidity $(\mathrm{RH}), 24 \mathrm{~h}$ at $22{ }^{\circ} \mathrm{C}$ and $85 \% \mathrm{RH}, 24 \mathrm{~h}$ at $20^{\circ} \mathrm{C}$ and $80 \% \mathrm{RH}$, sausages were transferred to different drying chambers for ripening. Control was maintained during 35 days until a weight loss of $33 \%$ and modified sausage was held during 21 days. Four batches of each type of sausage were made.

Analytical Methods. Proteolysis and Lipolysis Measure ments. Acidity values (grams of oleic acid per $100 \mathrm{~g}$ of fat) were determined using International Standard ISO 1740 (ISO, 1980). Total free $\alpha-\mathrm{NH}_{2}-\mathrm{N}$ groups were extracted with citrate buffer, and trichloroacetic acid (TCA) was added to precipitate the proteins. They were subsequently analyzed through a ninhydrin colorimetric method using tyrosine as the standard (Massi, 1963).

Likens-Nickerson Extraction. Twenty-five grams of frozen sausage was ground and placed in a $250 \mathrm{~mL}$ flask with 100 $\mathrm{mL}$ of water. A second flask with $5 \mathrm{~mL}$ of dichloromethane and $150 \mu \mathrm{g}$ of dodecane (i.s.) was also attached to a modified Likens-Nickerson apparatus. Five milliliters of dichloromethane was al so added to fill the apparatus solvent return loop. Both solvent and sample mixture were heated to $70{ }^{\circ} \mathrm{C}$ and boiling temperature, respectively, maintaining these conditions during $2 \mathrm{~h}$. After cooling to ambient temperature, the extract of dichloromethane was collected and dried over anhydrous $\mathrm{Na}_{2} \mathrm{SO}_{4}$. Three distillations per batch of sausage were carried out.

Analysis of Volatile Compounds. The volatile compounds were analyzed in an HP 6890 GC system (Hewlett-Packard) coupled to a 5973 mass sel ective detector (Hewlett-Packard). A total of $1 \mu \mathrm{L}$ of the extract was injected into the GC, equipped with a capillary column (30 $\mathrm{m} \times 250 \mu \mathrm{m}$ i.d. $\times 0.25 \mu \mathrm{m}$ film thickness, HP-5MS). The carrier gas was $\mathrm{He}(1 \mathrm{~mL} / \mathrm{min})$, and the chromatographic conditions were as follows: initial oven temperature was maintained during $10 \mathrm{~min}$ at $40{ }^{\circ} \mathrm{C}$ and subsequently programmed from 40 to $120^{\circ} \mathrm{C}$ at a rate of 3 ${ }^{\circ} \mathrm{C} / \mathrm{min}$ and at a rate of $10^{\circ} \mathrm{C} / \mathrm{min}$ from 120 to $250^{\circ} \mathrm{C}$, at which it was held for another $5 \mathrm{~min}$; injector temperature, $250{ }^{\circ} \mathrm{C}$; mass range, 33-350 amu; solvent delay, 4 min; electron impact at $70 \mathrm{eV}$.

I dentification of the peaks was based on comparison of their mass spectra with the spectra of the Wiley library and, in addition in some cases, by comparison of their retention time with those of standard compounds. The Kovats indices were also calculated according to the method of Tranchant (1982) and were compared with available literature data (Kondjoyan and Berdagué, 1996). Only known peaks are shown. Areas of peaks were measured by integration of the total ion current of the spectra or by calculation of the total area based on integration of a single ion. Semiquantitative determination of the volatile compounds was based on the ratio of their peak to that of dodecane (i.s.), and the results were expresed as nanograms of dodecane per gram of dry matter.

Data Analysis. Data analysis was carried out with an SPSS program. Values for acidity and total free $\alpha-\mathrm{NH}_{2}-\mathrm{N}$ groups are the mean of 8 determinations ( 2 batches of product per type of sausage and 4 determinations per batch were carried out). Values for volatile profiles are the mean of 12 determinations (3 distillations per batch of sausage and 2 injections per distillation were carried out). A Student t test was used to determine significant differences between the two types of sausages for every studied parameter in each phase. An analysis of variance (ANOVA) was used to determine differences among phases for every type of sausage along the ripening process.

\section{DISCUSSION}

A previous work with these two enzymes was carried out to select the most suitable dose to be subsequently employed simultaneously in the elaboration of chorizo de Pamplona. The enzymes were tested individually. Three different concentrations of Flavourzyme were assayed $(0.07,1$, and $2.8 \mathrm{LAPU} / \mathrm{g})$. Sensory analysis of these products revealed serious texture defects, suggesting that a lower dose of these enzyme should be used (Ansorena et al., 1997). The dose chosen was $0.02 \mathrm{LAPU} /$ g. Novozym 677BG was also tested at three different concentrations $(0.5,1.5$, and $3 \mathrm{LU} / \mathrm{g})$; all of them produced an increase in the acidity value (Ansorena et al., 1997). The lowest dose was chosen for this experiment $(0.5 \mathrm{LU} / \mathrm{g})$.

The lipolytic and proteolytic activities of the enzymes at the chosen doses were confirmed by the measure of the acidity values and the content of total free $\alpha-\mathrm{NH}_{2}$ groups, respectively. By the third day of ripening differences in the proteolytic activity were found be 
Table 3. Results of Profiles of Compounds Extracted by SDE

\begin{tabular}{|c|c|c|c|c|c|c|c|}
\hline \multirow[b]{2}{*}{$\mathrm{RI}$} & \multirow[b]{2}{*}{$\mathrm{RID}$} & \multirow[b]{2}{*}{ compound } & \multicolumn{2}{|c|}{ control } & \multicolumn{2}{|c|}{ Flavourzyme + Novozym } & \multirow[b]{2}{*}{ signifc } \\
\hline & & & mean & SD & mean & SD & \\
\hline & & acids & & & & & \\
\hline & & 2-methyl propanoic acid & 790.89 & 86.85 & 948.17 & 117.20 & ns \\
\hline & & butanoic acid & 5213.28 & 434.40 & 2823.04 & 399.77 & $* * *$ \\
\hline 848 & $\mathrm{~B}$ & 3-methylbutanoic acid & 15422.93 & 1006.43 & 9726.66 & 1878.19 & $* *$ \\
\hline 858 & B & 2-methylbutanoic acid & 4757.94 & 264.47 & 4023.00 & 488.18 & * \\
\hline 999 & A & hexanoic acid & 12809.47 & 1473.03 & 9359.68 & 2239.98 & $*$ \\
\hline 1188 & A & octanoic acid & 49202.69 & 6216.80 & 69621.44 & 13001.22 & $*$ \\
\hline 1386 & A & decanoic acid & 144008.96 & 18366.92 & 225711.84 & 36031.19 & $* *$ \\
\hline 1572 & $A$ & dodecanoic acid & 37490.09 & 5559.30 & 51319.10 & 10622.04 & ns \\
\hline 1774 & A & tetradecanoic acid & 100904.45 & 15857.18 & 211425.31 & 17746.43 & $* * *$ \\
\hline 1871 & $\mathrm{C}$ & pentadecanoic acid & 2458.02 & 987.88 & 4256.43 & 191.86 & $*$ \\
\hline 1957 & $A$ & 9-hexadecenoic acid & 59729.99 & 8031.46 & 126429.93 & 8638.42 & $* * *$ \\
\hline 1983 & A & hexadecanoic acid & 439392.08 & 68022.44 & 912943.22 & 78847.86 & $* * *$ \\
\hline 2113 & A & 9,12-octadecadienoic acid & 4444.02 & 894.21 & 9174.81 & 686.61 & $* * *$ \\
\hline 2123 & A & 9-octadecenoic acid & 737.89 & 180.41 & 1981.49 & 98.61 & $* * *$ \\
\hline \multirow[t]{4}{*}{2177} & A & octadecanoic acid & 348.43 & 32.93 & 643.88 & 48.13 & $* * *$ \\
\hline & & subtotal & $\begin{array}{r}877711.12 \\
46.36 \%\end{array}$ & & $\begin{array}{r}1640387.97 \\
64.40 \%\end{array}$ & & \\
\hline & & alcohols & & & & & \\
\hline & & ?-methyl-2-butenol & 1031.34 & 695.44 & nd & & \\
\hline 850 & C & 2-furanmethanol & 1393.39 & 115.93 & 813.19 & 89.45 & *** \\
\hline 1100 & A & linalool & 3964.62 & 320.68 & 4669.42 & 497.45 & ns \\
\hline \multirow[t]{3}{*}{1112} & $\mathrm{C}$ & phenylethyl alcohol & 4845.85 & 483.92 & 4409.43 & 254.91 & ns \\
\hline & & subtotal & $\begin{array}{r}11235.20 \\
0.59 \%\end{array}$ & & $\begin{array}{r}9892.04 \\
0.39 \%\end{array}$ & & \\
\hline & & aldehydes & & & & & \\
\hline 804 & $A$ & hexanal & 1697.55 & 86.20 & 2755.94 & 392.37 & $* *$ \\
\hline 828 & $\mathrm{~B}$ & 2-furancarboxal dehyde & 9190.02 & 600.25 & 9069.23 & 477.89 & ns \\
\hline 959 & $\mathrm{~B}$ & benzal dehyde & 2007.79 & 268.84 & 3066.31 & 771.71 & $*$ \\
\hline 1040 & $\mathrm{~B}$ & phenylacetaldehyde & 28653.54 & 2167.02 & 37858.84 & 3079.30 & $* *$ \\
\hline 1106 & $\mathrm{~B}$ & nonanal & 3599.00 & 510.42 & 3249.29 & 587.99 & ns \\
\hline 1615 & $\mathrm{~B}$ & tetradecanal & 227.34 & 152.40 & 200.49 & 24.63 & ns \\
\hline 1713 & $\mathrm{~B}$ & pentadecanal & 7019.42 & 917.00 & 5523.84 & 703.83 & * \\
\hline 1830 & $\mathrm{~B}$ & hexadecanal & 390769.80 & 60332.30 & 269281.35 & 24277.26 & $*$ \\
\hline 2009 & $\mathrm{~B}$ & octadecenal & 70600.09 & 7597.90 & 58793.00 & 3941.26 & ** \\
\hline \multirow[t]{3}{*}{2032} & $\mathrm{C}$ & octadecanal & 72181.41 & 4847.92 & 69428.66 & 4449.33 & ns \\
\hline & & subtotal & $\begin{array}{r}585945.96 \\
30.95 \%\end{array}$ & & $\begin{array}{r}459226.93 \\
18.03 \%\end{array}$ & & \\
\hline & & ketones & & & & & \\
\hline 1094 & $\mathrm{C}$ & 2-nonanone & 1338.61 & 352.02 & nd & & \\
\hline 1460 & $\mathrm{~B}$ & geranyl acetone & 4519.12 & 356.70 & 4486.80 & 939.59 & ns \\
\hline 1491 & $\mathrm{~B}$ & $\beta$-ionone & 4419.22 & 246.48 & 3405.08 & 376.84 & ** \\
\hline 1537 & $\mathrm{C}$ & $\begin{array}{l}\text { 5,6,7,7-a-tetrahydro-4,4,7a-trimethyl- } \\
\text { 2(4H)-benzofuranone }\end{array}$ & 3660.02 & 195.43 & 2522.82 & 217.99 & $* * *$ \\
\hline 1696 & $\mathrm{~B}$ & 2-pentadecanone & 15330.39 & 1119.67 & 8860.68 & 739.88 & $* * *$ \\
\hline \multirow[t]{3}{*}{1746} & $\mathrm{C}$ & $9 \mathrm{H}$-fluoren-9-one & 2518.08 & 216.36 & 2429.03 & 119.74 & ns \\
\hline & & subtotal & $\begin{array}{r}31785.43 \\
1.68 \%\end{array}$ & & $\begin{array}{r}21704.41 \\
0.85 \%\end{array}$ & & \\
\hline & & esters & & & & & \\
\hline 1003 & $\mathrm{~B}$ & hexanoic acid ethyl ester & nd & & 1257.30 & 143.86 & \\
\hline 1128 & A & octanoic acid methyl ester & 1366.13 & 68.86 & 2027.19 & 102.37 & $* * *$ \\
\hline 1328 & A & decanoic acid methyl ester & 5777.45 & 216.43 & 7446.08 & 1125.26 & * \\
\hline 1398 & B & decanoic acid ethyl ester & 7640.57 & 448.22 & 11084.48 & 1771.10 & ** \\
\hline 1531 & A & dodecanoic acid methyl ester & 463.98 & 5.07 & 565.48 & 42.66 & $* *$ \\
\hline 1597 & $\mathrm{~B}$ & dodecanoic acid ethyl ester & 1843.61 & 243.27 & 3037.03 & 320.58 & $* *$ \\
\hline 1725 & A & tetradecanoic acid methyl ester & 5060.54 & 754.20 & 9838.12 & 1203.70 & $* *$ \\
\hline 1805 & $\mathrm{~B}$ & tetradecanoic acid ethyl ester & 3884.81 & 401.55 & 9903.22 & 1168.94 & $* * *$ \\
\hline 1843 & $\mathrm{C}$ & tetradecanoic acid isopropyl ester & 6169.06 & 552.24 & nd & & \\
\hline 1938 & A & hexadecanoic acid methyl ester & 16764.60 & 1295.68 & 27717.68 & 1469.06 & $* * *$ \\
\hline 2005 & C & hexadecanoic acid ethyl ester & 16999.61 & 1501.16 & 43302.82 & 3581.44 & $* * *$ \\
\hline 2101 & A & 9,12-octadecadienoic methyl ester & 14366.96 & 683.74 & 28429.16 & 2372.57 & *** \\
\hline 2107 & $A$ & 9-octadecenoic methyl ester & 10363.59 & 858.67 & 29997.56 & 3787.84 & $* * *$ \\
\hline 2134 & A & octadecanoic methyl ester & nd & & 9617.38 & 1040.41 & \\
\hline \multirow[t]{2}{*}{2207} & $\mathrm{~B}$ & octadecanoic ethyl ester & nd & & 394.83 & 60.18 & \\
\hline & & subtotal & $\begin{array}{r}90700.91 \\
4.79 \%\end{array}$ & & $\begin{array}{r}184618.35 \\
7.25 \%\end{array}$ & & \\
\hline
\end{tabular}


Table 3 (Continued)

\begin{tabular}{|c|c|c|c|c|c|c|c|}
\hline \multirow[b]{2}{*}{$\mathrm{RI}^{\mathrm{a}}$} & \multirow[b]{2}{*}{$\mathrm{RID}^{\mathrm{b}}$} & \multirow[b]{2}{*}{ compound } & \multicolumn{2}{|c|}{ control } & \multicolumn{2}{|c|}{ Flavourzyme + Novozym } & \multirow[b]{2}{*}{ signifc } \\
\hline & & & mean & SD & mean & SD & \\
\hline & & sulfur compounds & & & & & \\
\hline 848 & $\mathrm{~B}$ & 3,3' -thiobis(1-propene) & 260.52 & 33.21 & 276.90 & 38.61 & ns \\
\hline 907 & $\mathrm{~B}$ & 3-(methylthio)propanal (methional) & 4402.61 & 794.89 & 5688.34 & 1274.03 & ns \\
\hline 912 & $\mathrm{C}$ & methyl 2-propenyl disulfide & 603.88 & 48.16 & 500.35 & 146.84 & ns \\
\hline \multirow[t]{4}{*}{1075} & $\mathrm{C}$ & di-2-propenyl disulfide & 8450.60 & 600.70 & 7567.63 & 1188.21 & ns \\
\hline & & subtotal & $\begin{array}{r}13717.61 \\
0.72 \%\end{array}$ & & $\begin{array}{r}14033.23 \\
0.55 \%\end{array}$ & & \\
\hline & & aromatic hydrocarbons & & & & & \\
\hline & & toluene & 579.30 & 10.64 & 496.81 & 66.07 & $*$ \\
\hline 858 & $\mathrm{~B}$ & xylene & 961.19 & 54.27 & 988.67 & 89.50 & ns \\
\hline 989 & $\mathrm{~B}$ & trimethyl-105/120-benzene (B) & 3647.80 & 330.68 & 2760.92 & 440.23 & $*$ \\
\hline 1017 & B & methyl-?-methylethyl benzene (?-cymene) & 1221.85 & 191.49 & nd & & \\
\hline 1175 & $\mathrm{C}$ & naphthalene & 1709.89 & 50.80 & 1965.29 & 110.16 & ** \\
\hline 1285 & $\mathrm{C}$ & methylnaphthalene & 1755.95 & 233.71 & 1923.23 & 228.32 & ns \\
\hline 1301 & $\mathrm{C}$ & methylnaphthalene & nd & & 1765.30 & 399.65 & \\
\hline 1446 & $\mathrm{C}$ & acenaphtene & 2528.90 & 146.87 & 1978.73 & 424.45 & ns \\
\hline 1565 & $\mathrm{D}$ & trimethylnaphthalene & 4619.46 & 327.09 & 4543.70 & 818.72 & ns \\
\hline 1584 & $\mathrm{C}$ & 9H-fluorene & 2963.51 & 304.61 & 2936.36 & 385.37 & ns \\
\hline \multirow[t]{3}{*}{1589} & $\mathrm{D}$ & trimethylnaphthalene & 4088.47 & 181.01 & 3434.46 & 790.06 & ns \\
\hline & & subtotal & $\begin{array}{r}24076.31 \\
1.27 \%\end{array}$ & & $\begin{array}{r}22793.46 \\
0.89 \%\end{array}$ & & \\
\hline & & terpenes & & & & & \\
\hline 930 & $\mathrm{~B}$ & $\alpha$-pinene & 2686.58 & 320.96 & 1568.90 & 39.17 & $* * *$ \\
\hline 971 & $A$ & sabinene & 6552.83 & 491.54 & 3257.62 & 121.48 & *** \\
\hline 1001 & B & 3-carene & 6032.82 & 1160.66 & 2660.30 & 389.85 & $* *$ \\
\hline \multirow[t]{3}{*}{1022} & A & limonene & 6458.40 & 659.42 & 4209.47 & 361.84 & $* *$ \\
\hline & & subtotal & $\begin{array}{r}21730.63 \\
1.15 \%\end{array}$ & & $\begin{array}{r}11696.31 \\
0.46 \%\end{array}$ & & \\
\hline & & phenols & & & & & \\
\hline 987 & B & phenol & 16272.43 & 1116.01 & 10906.67 & 502.47 & $* * *$ \\
\hline 1056 & $\mathrm{~B}$ & 4-methylphenol (p-cresol) & 11905.88 & 716.40 & 9842.39 & 531.95 & $* *$ \\
\hline 1079 & $\mathrm{~B}$ & 2-methylphenol (o-cresol) & 30749.18 & 2112.69 & 22504.83 & 948.67 & $* * *$ \\
\hline 1087 & $\mathrm{~B}$ & guaiacol (2-methoxyphenol) & 5030.07 & 297.57 & 3712.68 & 474.90 & $* *$ \\
\hline 1141 & $\mathrm{D}$ & ethylphenol & 1548.14 & 165.22 & 1502.63 & 64.46 & ns \\
\hline 1149 & $\mathrm{D}$ & 2-dimethylphenol & 5533.52 & 151.79 & 4789.95 & 457.62 & $*$ \\
\hline 1151 & $\mathrm{D}$ & 2-dimethylphenol & 5994.92 & 358.01 & 4689.92 & 283.79 & ** \\
\hline 1168 & $\mathrm{D}$ & ethylphenol & 5611.27 & 424.73 & 3416.12 & 209.15 & $* * *$ \\
\hline 1170 & $\mathrm{D}$ & 2-dimethylphenol & 14007.86 & 2097.99 & 9681.41 & 437.80 & ** \\
\hline 1178 & $\mathrm{D}$ & 2-dimethylphenol & 4335.60 & 476.71 & 4006.70 & 466.03 & ns \\
\hline 1190 & $\mathrm{D}$ & 2-methoxy-4-methylphenol & 12689.04 & 1101.45 & 10630.04 & 1330.06 & ns \\
\hline 1192 & D & 3-dimethylphenol & 5156.99 & 582.89 & 3772.87 & 403.61 & ** \\
\hline 1219 & $\mathrm{C}$ & 4-vinylphenol & 10006.65 & 547.65 & 7434.16 & 885.80 & ** \\
\hline 1238 & D & methylethylphenol & 2529.32 & 134.15 & 1990.15 & 167.44 & ** \\
\hline 1244 & $\mathrm{D}$ & dimethoxyphenol & 4490.48 & 354.51 & 3249.14 & 318.21 & ** \\
\hline 1259 & D & ?-methyl-?-ethylphenol & 3592.82 & 366.38 & 3798.71 & 210.10 & ns \\
\hline 1265 & $\mathrm{D}$ & trimethylphenol & 1608.56 & 149.87 & 1582.47 & 192.08 & ns \\
\hline 1270 & $\mathrm{D}$ & trimethylphenol & 1885.12 & 182.55 & 1515.51 & 81.48 & $*$ \\
\hline 1277 & $\mathrm{C}$ & 4-ethyl-2-methoxyphenol & 11259.57 & 1184.91 & 7581.67 & 1146.94 & ** \\
\hline 1311 & $\mathrm{~B}$ & 4-vinyl-2-methoxyphenol & 14729.11 & 1037.38 & 13650.01 & 2038.70 & ns \\
\hline 1355 & $\mathrm{C}$ & 2,6-dimethoxyphenol & 14711.02 & 1775.20 & 8837.54 & 1720.11 & $* *$ \\
\hline 1361 & $\mathrm{~B}$ & eugenol & 1608.54 & 152.84 & 1308.14 & 89.87 & $*$ \\
\hline 1371 & C & 2-methoxy-4-propylphenol & 4492.82 & 555.19 & 3125.60 & 367.02 & $* *$ \\
\hline \multirow[t]{3}{*}{1454} & $\mathrm{C}$ & isoeugenol & 1829.35 & 156.57 & 1357.12 & 198.37 & $*$ \\
\hline & & subtotal & $\begin{array}{r}191578.25 \\
10.12 \%\end{array}$ & & $\begin{array}{r}144886.42 \\
5.69 \%\end{array}$ & & \\
\hline & & nitrogen compounds & & & & & \\
\hline 1063 & $\mathrm{~B}$ & 2-acetylpyrrole (1058) & 1786.82 & 148.13 & 1660.41 & 298.46 & ns \\
\hline \multirow[t]{3}{*}{1086} & $\mathrm{C}$ & tetramethylpyrazine & 4369.79 & 169.77 & 4148.27 & 668.96 & ns \\
\hline & & subtotal & $\begin{array}{r}6156.61 \\
0.33 \%\end{array}$ & & $\begin{array}{r}5808.68 \\
0.23 \%\end{array}$ & & \\
\hline & & others & & & & & \\
\hline 806 & B & tetrachloroethylene & 2106.32 & 152.60 & 1387.77 & 189.21 & $* * *$ \\
\hline 1315 & C & 1,2,3-trimethoxybenzene & 2477.84 & 81.92 & 2340.44 & 259.13 & ns \\
\hline 1407 & $\mathrm{C}$ & 1,2,3-trimethoxy-5-methylbenzene & 5617.37 & 482.32 & & & $* *$ \\
\hline 1515 & $\mathrm{C}$ & dibenzofuran & 6534.71 & 342.66 & 5182.51 & 883.25 & $*$ \\
\hline 1533 & $\mathrm{D}$ & 2,3,5-trimethoxytoluene ?? & 8963.66 & 1296.35 & 5821.33 & 729.06 & ** \\
\hline \multirow[t]{2}{*}{1797} & $\mathrm{C}$ & anthracene & 8286.51 & 907.66 & 9119.20 & 1078.15 & ns \\
\hline & & subtotal & $\begin{array}{r}33986.42 \\
1.80 \%\end{array}$ & & $\begin{array}{r}23851.26 \\
0.94 \%\end{array}$ & & \\
\hline
\end{tabular}


Table 3 (Continued)

\begin{tabular}{|c|c|c|c|c|c|c|c|}
\hline \multirow[b]{2}{*}{$\mathrm{RI}^{\mathrm{a}}$} & \multirow[b]{2}{*}{$\mathrm{RID}^{\mathrm{b}}$} & \multirow[b]{2}{*}{ compound } & \multicolumn{2}{|c|}{ control } & \multicolumn{2}{|c|}{ Flavourzyme + Novozym } & \multirow[b]{2}{*}{ signifc } \\
\hline & & & mean & SD & mean & SD & \\
\hline \multirow[t]{3}{*}{$\begin{array}{r}900 \\
1500\end{array}$} & B & $\begin{array}{l}\text { alkanes } \\
\text { nonane } \\
\text { pentadecane }+99\end{array}$ & $\begin{array}{c}\text { nd } \\
4546.25\end{array}$ & 311.36 & $\begin{array}{l}5688.34 \\
2644.91\end{array}$ & $\begin{array}{r}1274.03 \\
447.11\end{array}$ & *** \\
\hline & & subtotal & $\begin{array}{r}4546.25 \\
0.24 \%\end{array}$ & & $\begin{array}{r}8333.25 \\
0.33 \%\end{array}$ & & \\
\hline & & total & 1893170.69 & & 2547232.3 & & \\
\hline
\end{tabular}

a $\mathrm{RI}$, retention indices for the DB5 column. ${ }^{\mathrm{b}} \mathrm{RID}$, reliability of identification, indicated by the following symbols: A, mass spectrum and retention time identical with those of an autentic sample; $B$, mass spectrum and Kovats index in agreement with the corresponding literature data; C, mass spectrum consistent with spectra reported in the Wiley library data; D, tentative identification by mass spectrum. nd:not detected. ' Significance: ns, not significant; *, p < 0.05; **, p $<0.01$; ***, p $<0.001$. Results expressed in nanograms of dodecane per gram of dry matter.

tween the two batchess; the concentration of total free $\alpha-\mathrm{NH}_{2}$ groups was higher in the sausage with enzymes (Table 1). Between the third and ninth days of ripening, the value for the enzyme-containing sausage was similar to that for the control batch at the end of the maturation. A similar effect was observed for the acidity value, with the lipolytic activity of Novozym being shown al so from the third day of ripening (Table 2). At the end of the process both parameters were higher in the modified sausages, despite the shorter maturation time.

Table 3 shows the volatile profile of compounds extracted by SDE and analyzed by GC-MS. A total of 104 different substances were identified between the two types of analyzed sausages, which were grouped into 11 chemical families: phenols (24), acids (15), esters (15), aromatic hydrocarbons (11), al dehydes (10), ketones (6), alcohols (4), sulfur compounds (4), terpenes (4), nitrogen compounds (2), and others (7). Expressed in milligrams of dodecane per gram of dry matter, a total of $2.5 \mathrm{mg}$ was extracted in the modified sausage, and $1.9 \mathrm{mg}$ was the amount extracted in the control. However, the amounts of only two chemical groups was clearly greater in the enzyme-containing sausages: acids and esters.

The most affected fraction by the use of the enzymes was the esters, which increased their concentration by $103.5 \%$ in the modified sausages with regard to the control, due to the increment in the long-chain fatty acid esters $\mathrm{C}_{16}$ and $\mathrm{C}_{18}$. The contribution of this group to the total area was $4.8 \%$ for the control batch and $7.3 \%$ for the modified one. This increment in esters could be related to the great lipolytic activity suffered by the enzyme-containing sausages, which led to a greater amount of free fatty acids. These compounds are the substrate for microorganisms to the synthesis of esters. Esters are detected in products with a high concentration of acids and alcohols (Stahnke, 1994). Ethyl esters are formed by enzymatic reaction between acids and ethanol (Hinrichsen and Pedersen, 1995).

Acids were quantitatively the most abundant group in both types of sausages, accounting for 46 and $64 \%$ of the total area in the control and enzyme-containing sausages, respectively. This increment (87\%) in their concentration was mainly due to the presence of longchain fatty acids. They do not contribute directly to the flavor of the dry fermented sausages but could be substrates for lesser flavoring compounds of lower threshold value and greater volatility.

Concentration of some acids from the microbial degradation of ramified amino acids, 2-methyl butanoic acid and 3-methylbutanoic acid, was lower in the sausages with enzyme. These compounds possess very strong, cheesy odors that will be of importance and also may have a positive impact on aroma due to conversion into fruity esters (Stahnke, 1995). No differences were found for 2-methyl propanoic acid. However, the concentration of phenylacetaldehyde, an aldehyde originated from the microbial degradation of phenylalanine and suggested as a proteolysis indicator, was significantly higher in the sausage with enzymes. Berdagué et al. (1993) pointed out that the proteolysis accounted for $\sim 6 \%$ of the total compounds extracted with dynamic headspace from an unspiced dry sausage. They concluded that this low percentage of compounds derived from amino acids was due to a restricted proteolysis because of inhibitory physicochemical conditions (low water activity, high salt contents, and low pH values). Our results showed that in the sausages with enzymes there was a significantly greater proteolytic activity. It could be that the shorter ripening time was not enough to allow the devel opment of secondary reactions which would lead to some of the compounds.

Aldehydes content decreased significantly from 31 to $18 \%$ due to the lower amounts of pentadecanal, hexadecanal, and octadecanal. As suggested by Dirinck et al. (1997), these high molecular weight aldehydes could act as precursors for the volatile alkanals and alkenals. The higher amount of hexanal found in the modified sausages could support this hypothesis.

García Regueiro et al. (1998) found a higher release of terpenes in dry fermented sausages elaborated with a highly proteolytic strain of Staphylococus xyl osus LTH 2102. They concluded that the higher degradation of proteins can reduce the interaction of terpenes and proteins. The use of the mixture Flavourzyme and Novozym did not contribute to the increased content of terpenes, which was greater in the control sausage $(1.15 \%)$ than in the the modified sausage $(0.46 \%)$.

Sulfur compounds originated from garlic and did not show significant differences, and neither did most of the aromatic hydrocarbons. Phenols showed, in general, greater amounts in the control sausage. Compounds of these chemical groups were not related to the use of exogeous enzymes.

In summary, the addition of the enzymes Novozym and Flavourzyme at the assayed doses led to higher and faster proteolytic and lipolytic activities in the modified sausages with regard to the control, despite their shorter ripening time. Esters and acids were the most affected chemical groups among those compounds extracted by $\mathrm{SDE}$. The greater proteolysis in the sausages with enzymes did not have result in the expected increment 
of amino acid derivatives. Other chemical groups were not affected by the addition of the enzymes.

\section{ACKNOWLEDGMENT}

We thank Novo Nordisk A/S for the supply of enzymes and Prof. Mohino for scientific advice.

\section{LITERATURE CITED}

Ansorena, D.; Zapelena, M. J .; Astiasarán, I.; Bello, J . Activity of Flavourzyme and Novozym 677BG in the manufacture of Chorizo de Pamplona. In VII Meeting on Industrial Application of Enzymes; AIQS: Barcelona, Spain, 1997; $p$ 163.

Ansorena, D.; Zapelena, M. J .; Astiasarán, I.; Bello, J . Simultaneous addition of Palatase $\mathrm{M}$ and Protease $\mathrm{P}$ to a dry fermented sausage (Chorizo de Pamplona) elaboration: effect over peptidic and lipid fractions. Meat Sci. 1998, 50 (1), 37-44.

Berdagué, J . L.; Monteil, P.; Montel, M. C.; Talon, R. Effects of starter cultures on the formation of flavour compounds in dry sausage. Meat Sci. 1993, 35, 275-287.

Bruna, J .; Fernández, M.; Hierro, E.; de la Hoz, L.; Ordóñez, J. A. Use of Penicillium olsonii extracts to potentiate the dry fermented sausage flavour. In 44th I COMS; Barcelona, Spain, 1998; pp 800-801.

Díaz, O.; Fernández, M.; García de Fernando, G. D.; de la Hoz, L.; Ordoñez, J . A. Effect of the addition of Papain on the dry fermented sausage proteolysis. J . Sci. Food Agric. 1996, $71,13-21$.

Díaz, O.; Fernández, M.; García de Fernando, G. D.; de la Hoz, L.; Ordoñez, J. A. Proteolysis in dry fermented sausages: the effect of selected exogenous proteases. Meat Sci. 1997, 46 (1), 115-128.

Dirinck, P.; Van Opstaele, F.; Vandendriessche, F. Flavour differences between nothern and southern European cured hams. Food Chem. 1997, 59 (4), 511-521.

Fernández, M.; de la Hoz, L.; Díaz, O.; Cambero, M. I.; Ordóñez, J . A. Effect of the addition of pancreatic lipase on the ripening of dry-fermented sausages-Part 2. Free fatty acids, short-chain fatty acids, carbonyls and sensory quality. Meat Sci. 1995, 40, 351-362.

García-Regueiro, J. A.; Díaz, I. Aplicaciones del análisis de volátiles en productos cárnicos. Eurocarne 1995, 38, 8590.

García-Regueiro, J. A.; Rius, M. A.; Hortós, M.; Hugas, M., Díaz, I. Influence of starter cultures on the volatile profile of a Spanish dry fermented sausage (fuet). In 44th ICOMS; Barcel ona, Spain, 1998; pp 802-803.

Hagen, B. F.; Berdagué, J . L.; Holck, A. L.; Naes, H.; Blom, $\mathrm{H}$. Bacterial proteinase reduces maturation time of dry fermented sausages. J . F ood Sci. 1996, 61 (5), 1024-1029.
Hinrichsen, L. L.; Pedersen, S. B. Relationship among flavor, volatile compounds, chemical changes, and microflora in I talian-type dry-cured ham during processing. J . Agric. Food Chem. 1995, 43, 2932-2940.

ISO. Determination of acidity content. ISO 1740-1980. In International Standards Meat and Meat Products; I nternational Organization for Standarization: Ginebra, 1980.

Kondjoyan, N.; Berdagué, J. L. A Compilation of Relative Retention Indices for the Analysis of Aromatic Compounds; Laboratoire Flaveur (INRA): Theix, France, 1996.

Massi, O. La scomposizione proteica nei prosciutti qualeindice del processo di maturazione. Vet. Ital. 1963, 14, 957-964.

Ordóñez, J. A.; Fernández, M.; Hierro, E.; Bruna, J. M.; Herranz, B.; de la Hoz, L. Consideraciones acerca de la maduración acel erada de embutidos crudos curados. Eurocarne 1998, 68, 53-57.

Stahnke, L. H. Aroma compounds from dried sausages fermented with Staphylococcus xylosus. Meat Sci. 1994, 38, 39-53.

Stahnke, L. H. Dried sausages fermented with Staphyl ococcus xyl osus at different temperatures and with different ingredient levels-Part II. Volatile components. Meat Sci. 1995, 41 (2), 193-209.

Tranchant, J . Manuel PratiquedeChromatographieen Ohase Gazeuse; Masson: Paris, France, 1982; pp 301-337.

Zalacain, I.; Zapelena, M.J .; De Peña, M. P.; Astiasarán, I.; Bello, J. Use of lipase from Rhizomucor miehei in dry fermented sausages elaboration. Microbial, chemical and sensory analysis. Meat Sci. 1997a, 45 (1), 99-105.

Zalacain, I.; Zapelena, M. J .; De Peña, M. P.; Astiasarán, I.; Bello, J . Lipid fractions of dry fermented sausages change when starter culture and/or Aspergillus lipase are added. J . Food Sci. 1997b, 62 (5), 1076-1079.

Zalacain, I.; Zapelena, M. J .; De Peña, M. P.; Astiasarán, I.; Bello, J . Application of Li ipozyme 10.000L (from Rhizomucor miehei) in dry fermented sausage technology: study in a pilot plant and at the industrial level. J . Agric. Food Chem. 1997c, 45, 1972-1976.

Zapelena, M. J .; Ansorena, D.; Zalacain, I.; Astiasarán, I.; Bello, J. Dry fermented sausages manufactured with different amounts of commercial proteinases: evolution of total free $\alpha-\mathrm{NH}_{2}-\mathrm{N}$ groups and sensory evaluation of the texture. Meat Sci. 1998, 49 (2), 213-221.

Zapelena, M. J .; Astiasarán, I.; Bello, J. Dry fermented sausages made with a protease from Aspergillus oryzaeand/ or a starter culture. Meat Sci. 1999, 52, 403-409.

Received for review August 23, 1999. Revised manuscript received March 21, 2000. Accepted March 21, 2000. We thank the Goverment of Navarra and the Roviralta Foundation for financial support.

J F 990931Y 